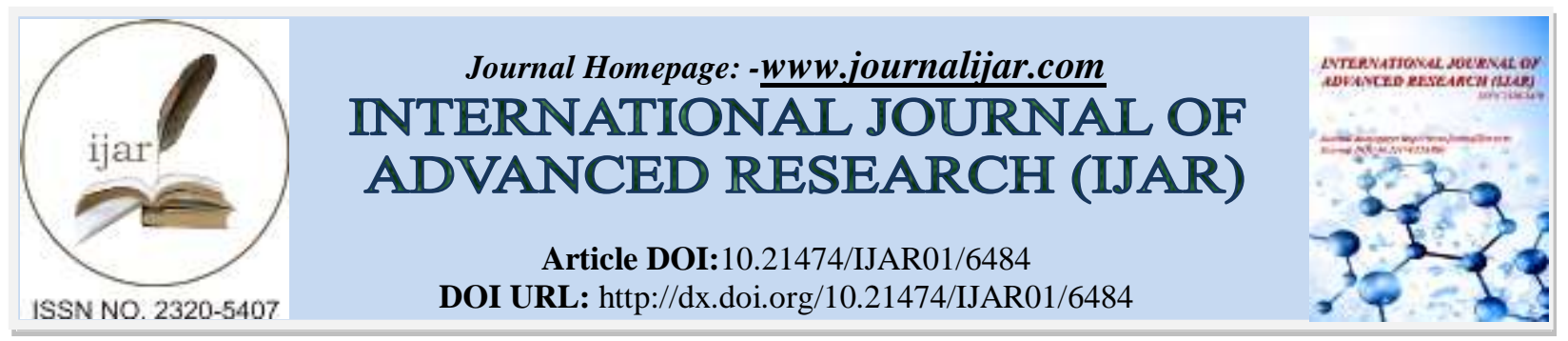

RESEARCH ARTICLE

\title{
DESIGN AND VALIDITY OF MODULE BASED ON CONCEPT MAP IN THE COURSE OF EVOLUTION.
}

\author{
M. Wati. V. Fitriani and RRP. Megahati.
}

Biology Education Department STKIP PGRI Sumatera Barat, Padang, West Sumatera, Indonesia.

\section{Manuscript Info}

Manuscript History

Received: 09 December 2017

Final Accepted: 11 January 2018

Published: February 2018

Keywords:-

Design, validity test, module, concept map, evolution course.

\section{Abstract}

Students' learning outcomes are low in evolutionary courses because the students are not able to master the concepts contained in the evolution course and there is no module that can be students. The purpose of this research is to develop a module based on concept map in evolution course. The type of research used is research and development using 4-D model, consisting of 4 stages namely defined, design, develop, and disseminate which is limited to development stage (validity). The results showed that the development of module based on concept map in the evolution course is very valid criteria with the validity value of $92.18 \%$. The result of module based on concept map validation on the evolution course has been used by lecturers and students.

Copy Right, IJAR, 2018, All rights reserved.

\section{Introduction:-}

The course of evolution must be followed by students in the 6th semester at STKIP PGRI Sumatera Barat.During the learning process, students find it difficult to understand the concepts contained in the course of evolution. Students do not have a sourcebook to study consequently low student learning outcomes. Therefore, it is necessary to design a module based on concept map in the course of evolution as reading material or reference students. Suggest in the module based on concept map can attracted students in reading because of the material presented in the form of concept maps making it easier for students to understand the concepts of evolution. The module is a textbook is written or smallest teaching program with the aim to allow students to learn independently without or with minimal guidance from the lecturers.

A module as a teaching material systematically arranged in an easily understood by students according to students level of knowledge and age, so that they can learn on their own with minimal assistance from educators (Prastowo, 2011).Concept maps proved to be an effective way to represent and contrast the students' understanding of various concepts throughout time (Okada, 2014). The aim of this study is to develops of module based on concept map in evolution course.

\section{Material and Methods:-}

The study was conducted on the even semester of 2016/2017 on the Biology education department of STKIP PGRI Sumatera Barat. The type of research used is research and development with using 4-D model, consisting of 4 stages ie defined, design, develop, and disseminate (Trianto,2010). This research limited to development stage (validity) and the design stage modules accordance with the curriculum and course material on evolution. The module-based

Corresponding Author:-M. Wati, V. Fitriani.

Address:-Biology Education Department STKIP PGRI Sumatera Barat, Padang, West Sumatera, 
on concept map validity test is performed by three validators. Aspects assessed in the module validity test included aspect of material, aspects of graffiti and aspect of language

\section{Result and discussion:-}

This research is done by using 4-D development model which consists of 4 stages, namely defined, design, develop, and disseminate which is limited to development stage (validity).

\section{Defined stage:-}

In the defined stage, curriculum and student analysis is performed

\section{Analysis of curriculum:-}

The curriculum associated with the resulting product is a standard and basic competencies. Competency standards for subjects are to understand the evolution include principles and theories of evolution, evolution, evidence for evolution, Hardy-Weinberg law, natural selection and adaptive radiation, biogeography, mechanisms of speciation and extinction, and evolution of primates and humans. Competency standards are then translated into a number of core competencies and indicators that will facilitate students to the standards of competence. The results of the curriculum analysis are used to determine the required concepts in designing the concept map-based module in the course of evolution in STKIP PGRI Sumatera Barat.

\section{Analysis of student:-}

The analysis was conducted by interviewing some students of the faculty and students of Biology education department STKIP PGRI Sumatera Barat. Interviews were conducted to analyze the students, in terms of age, cognitive abilities, psychomotor abilities, and social skills. Interviews with several lectures who taught in Biology education department STKIP PGRI Sumatera Barat said that the students in 2013 have different characteristics both in learning (understanding the lessons) or when interacting with friends and surroundings, the views from the age levels of students aged between 18-21 years. Budiningsih (2005) children who are in the age of 18-21 years have been able to progress essential feature of abstract thinking, logic, draw conclusions, interpret and generate hypotheses and psychomotor abilities, ability to younger students in 2013 to the level of cognitive and psychomotor showed varying results, ie students who study at STKIP PGRI Sumatera Barat mostly come from different regions of the island of Sumatera and Java. Students have a variety of different capabilities due to differences in the recent education majors, national origin and family circumstances (in particular the social level) varies. This can happen even if they are selected before joining a student at PGRI STKIP Sumatera Barat. In terms of social capability, students in 2013 like cooperation and mutual help among peers. It can be seen from any work or group work performed during the lectures, they actively discuss together to solve problems or lecture material faced each meeting. They also help each other if there is a friend in need of help, especially in terms of understanding the lecture material.

Generally students for 18-21 years age levels have a good social attitude, namely the mutual assistance between them both in terms of social or academic. Not only the environment of the campus community environment as well. Judging from Interesting in using the media, the use of the media helps them in understanding and learning can increase their motivation to learn. From the beginning of the course, the students are able to utilize some type of media, and they have also been taught to make several types of media in accordance with the purpose of learning, so as to increase the understanding of students to understand the material being taught. Some media had the They use and create them included in the original media, mounted media, media models, graphic media and electronic media. So we can conclude the students are already using a lot of media in lectures. Based on the above analysis of the student, a map-based module concept developed in accordance with the level of ability of the students who have been able to think logically and clever put themselves in a moral owned in the application of the knowledge obtained so as to achieve the learning objectives in the course of evolution.

\section{Design stage:-}

At the design stage has been made a prototype module based on concept map in the course of evolution, namely :

1. Designing the module based on concept map framework

2. Module based on concept map has been developed for the course of evolution have components, such as the identity of subjects, units of the curriculum, materials, example problems and problem-solving that is easy to understand, about the formative and summative questions. 
3. Curriculum analysis contained in the syllabus, the standard analytical competence, basic competence, indicators, and material.

4. Access various relevant references from various sources and from the internet as writing materials.

5. Using appropriate sentences and easy to understand. Selection of the font is Comic Sans MS, font size 12 and 1.5 spacing.Views textbook made attractive and easy to understand.

6. Evaluate textbook writing by way of re-read, and getting feedback from others after reading it.

7. Fixing the sentences in the module according to the deficiencies found.

Module design based on concept map, on the material principle and the theories of evolution, evidences of evolution, law of Hardy-Weinberg, natural selection and radiation adaptation, biogeography, mechanisms of speciation and extinction, and evolution of primates and humans showed identity module, unit curriculum, materials, sample questions and discussion, and learning activities. This is in accordance with the opinion of Prastowo (2011) states that in making good teaching materials should there be achieved student competencies. Concept map approach for improving student's learning performance with an instant feedback mechanism, the result is significantly beneficial to promote learning achievement as well as the learning attitudes of a student (Wu et al., 2011). Schwandimann (2015) show that concept map as learning, metacognitive, collaborative, and assessment tool to support integrating complex idea. The concept map can be implemented in a wide variety of setting, from versatile tool to professional education, that only how to choose the type of concept map.

\section{Develop stage (Validity test):-}

Validation results from three validators to a module based on concept map in the evolution course include three aspects. Aspects assessed in the module validity test included the aspect of the material, aspects of graffiti and aspect of language. This is in accordance with the opinion Lestari (2013) which states that the instrument to assess a good teaching material is to include aspects the material, aspects of graffiti and aspect of language. So, with the assessment of the three aspects above then teaching materials will be judged worthy or not to use. The data is then processed so as to obtain the average the value of the validity of the module based on concept map can be seen in this below Table.

Table:-Results of module based on concept map validation the course of evolution.

\begin{tabular}{|c|c|c|c|}
\hline No. & Assessment standards & The value of validity (\%) & Criteria \\
\hline 1 & Aspects of material & 95.45 & Very Valid \\
\hline 2 & Aspects of graffiti & 96.87 & Very valid \\
\hline 3 & Aspects of language & 84.21 & Valid \\
\hline \multicolumn{2}{|c|}{ Average } & $\mathbf{9 2 . 1 8}$ & Very valid \\
\hline
\end{tabular}

Validity value on the aspect of material is $95.45 \%$ with very valid criteria. This is because the student analysis has been done and the material contained in the module is in accordance with the curriculum.

Module validation results from aspects of graffiti have been included in the very valid category with the validity value of $96.87 \%$. Aspects assessed from graffiti include the presentation of concept maps, fonts, and display design. This is in accordance with Lufri., et al (2007) states that learning by concept map can help students develop thinking strategies. Besides, to arrange good teaching materials, the arrangement of the appearance must also be clear and interesting. This is also in accordance with the opinions expressed Angkowo and Kosasih (2007) that concept maps can help students in understanding the concepts of the material

The result of the aspect of language validation has been included in the valid category with the validity value of $84.21 \%$. Aspects of the language assessed include readability and clarity of information, the appropriateness of writing with spelling and the use of effective and efficient language. This is consistent with Lestari's opinion (2013) which states that the use of language and sentence in a teaching material must be clear and easy to understand. So, using simple language and sentence will make it easier for students to understand the material contained in the module.

Results of the validity test of module based on concept map have been referring to very valid. A concept map can be used as a way to build knowledge structure of teachers in planning teaching materials. Map concept is a general overview of a concept that is interrelated with other concepts, giving rise to a clear understanding of the concepts used. Map concept as a diagram that shows the interplay between concepts as representative of the meaning (Lufri et 
al., 2007). Concept maps can be created with the working steps are simple, identify the main idea covers a number of concepts, identify the concepts of secondary support the main concept, placing the main concepts in the middle or the top of the map, and place the concepts of secondary around the main concept which visually shows the relationships between those concepts.

The validity test of student worksheets based on contextual teaching and learning in materials of algebra factorization have been referring to valid (Zulyadaini, 2017). The validity test of student worksheets based on mastery learning in genetics subject have been referring to valid (Megahati et al., 2016). The result of module based on concept map validation on the evolution course has been used by lecturers and students

\section{Acknowledgement:-}

The authors thank the Directorate of high education (DIKTI) which has given funding this research.

\section{References:-}

1. Angkowo, R and Kosasih A. (2007). Optimalisasi Media Pembelajaran. Grasindo. Jakarta.

2. Lestari, I. 2013. Pengembangan Bahan Ajar Berbasis Kompetensi.Padang: AkamediaPermata

3. Lufri., Arlis, Yunus Yuslidar, and Sudirman. (2007). Strategi Pembelajaran Biologi. Padang: UNP Press.

4. Megahati, R. R. P., Susanti, D and Yanti, F (2016). The validity test of student worksheet based on mastery learning in genetics subject. Unnes Journal of Biology Education, 5(1): 50-54.

5. Okada. (2014). Knowledge Cartography: Software Toolsand Mapping Techniques, Advanced Information and Knowledge Processing.

6. Prastowo, A. 2011. Panduan Kreatif Membuat Bahan Ajar Inovatif.Yogyakarta. DIVA press.

7. Schwandimann, B A. (2015). Concept maps as a versatile tool to integrate complex Ideas: From Kindergarten to Higher and Professional Education. Knowledge Management \& E. Learning: An International Journal (KM \& EL). 7(1).

8. Trianto. (2010). Mendisain Model Pembelajaran Inovatif dan Progresif. Kencana. Jakarta.

9. Wu, PW., Hwang, GJ., Milrad, M., Ke, HR., Huang, Y-M. An Innovation concept map approach for improving students' learning performance with ant instant feedback mechanism. British Journal of Educational Technology (BJET). 43(2)

10. Zulyadaini. (2017).A development of students' worksheet based on contextual teaching and learning. IOSR Journal of Mathematics. 13(1): 30-38. 